\title{
The trend from 1934 to 2001 of metal concentrations in bivalve shells (Unio pictorum) from two small lakes: Lake Levico and Lake Caldonazzo (Trento Province, Northern Italy)
}

\author{
Oscar RAVERA*, Pier Renato TRINCHERINI ${ }^{1}$, Gian Maria BEONE ${ }^{2)}$ and Bruno MAIOLINI ${ }^{3)}$ \\ CNR Institute of Ecosystem Study, Largo V. Tonolli 50, 28922 Verbania, Italy \\ ${ }^{1)}$ Joint Research Centre of European Comm., IES, 21027 Ispra, Varese, Italy \\ ${ }^{2)}$ Istituto di Chimica Agraria e Ambientale, Università Cattolica del Sacro Cuore, 29100 Piacenza, Italy \\ ${ }^{3)}$ Museo Trentino di Scienze Naturali, 38100 Trento, Italy \\ *e-mail corresponding author: o.ravera@ise.cnr.it
}

\begin{abstract}
This research follows the variations in calcium and 14 trace metal concentrations in mussel shells (Unio pictorum) from two lakes with different trophic levels, Lake Levico and Lake Caldonazzo (Northern Italy) from 1934 to 2001. During this period, the concentration of 11 trace metals increased and that of 3 decreased in the shells from Lake Levico, while the shells from Lake Caldonazzo showed an increase in the concentration of 6 metals, a decrease in 6 and no variation in 2. In both the lakes the concentration increases were far greater than the concentration decreases. In 1934 as well as in 2001 the metal concentrations in the shells from Lake Levico were higher than those from Lake Caldonazzo, although the concentrations of the most abundant metals in the filtered water of the latter lake were higher than those found in the water from Lake Levico. This apparent anomaly, also observed in an earlier study on the same species in 12 lakes, seems to be the combined effect of several causes (e.g. trophic level of the environment, metal concentration in the food), among which metal speciation in the water is probably one of the most important.
\end{abstract}

Key words: freshwater bivalve, trace metals, Lake Levico, Lake Caldonazzo, Unio pictorum

\section{INTRODUCTION}

A number of environmental variables (e.g. quality and abundance of food, type of substrate, temperature, oxygen and calcium concentrations, $\mathrm{pH}$, pollutants) influence the growth-rate and chemical composition of molluscs.

Because of the relatively rapid turnover-time of the soft tissues, their chemical composition should reflect the recent situation of the environment, whereas the slow turnover-time of the shell means that its chemical composition reflects the environmental situation integrated over a time corresponding to the age of the mollusc. As a consequence, the soft tissues are commonly analysed to monitor the recent pollution level of the environment, while the shell is a useful tool for following the trend of some environmental variables over time.

Accordingly, some authors have studied the bivalve shell to follow the variations over time of some environmental characteristics such as trophy, acidification, and metal pollution (e.g. Imaly 1982; Carell et al. 1995; Frantsevitch et al. 1996; Westermark et al. 1996, 1997; Nystrom et al. 1996). For example, seasonal variations of manganese level in Unio tumidus shell were highlighted for each year from 1977-1981 using high-resolution elemental mapping with nuclear microscope analyses (Mutvei \& Westermark 2001). These variations were related to oxygen depletion and eutrophication of the environment. Nelson (1964) followed the trend of fall-out contamination by nuclear tests in the Pacific Ocean by measuring the Sr-90 activity in the shell layers of Unionidae.

This research aims to compare the trend of 15 metal concentrations in Unio pictorum, L. shells from Lake Levico and Lake Caldonazzo (Trento Province, Northern Italy) during a period ranging from 1934 to 2001.

\section{STUDY SITE}

Lake Levico and Lake Caldonazzo, which lie in the upper Valsugana Valley (Trento Province, Northern Italy), are the source of the River Brenta (Fig. 1). Both lakes are essentially fed by springs and the water table, in addition to the water load from a small number of minor tributaries and rainfall. The lakes were carved out by the Quaternary glaciers and barred by alluvial conoids accumulated by their tributaries. Both lakes are excavated out of gneiss and quartziferous phyllites, and the water load from their tributaries is rich in calcium and magnesium, in addition to morainic and porphyric mud. A hilly Pliocene ridge separates the two lake watersheds (Trener 1952). The most important characteristics of the lakes are reported in table 1.

The first information on the trophic state of these lakes was provided by Marchesoni (1952a; 1952b) during the period from 1947 to 1949 . According to this author, both lakes were eutrophic, but Lake Levico was 


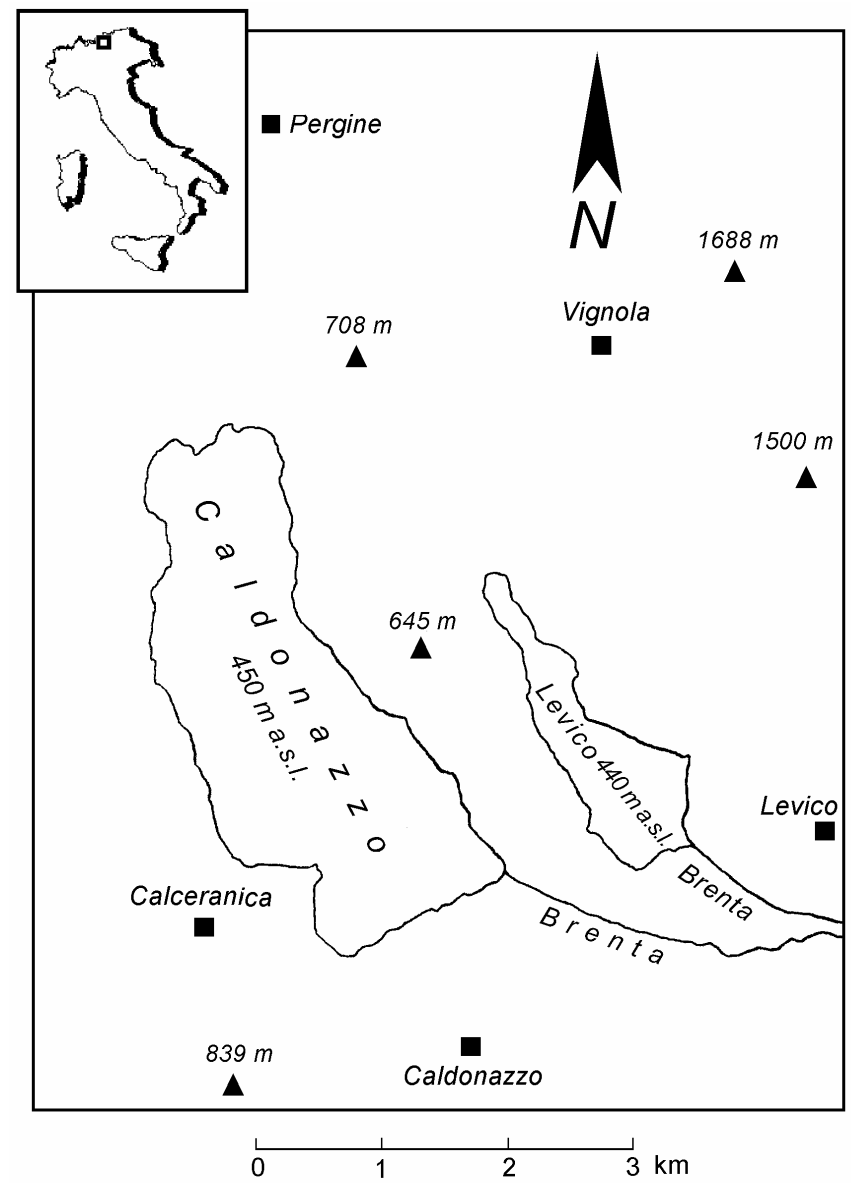

Fig. 1. Map of Lake Levico and Lake Caldonazzo. The black squares are towns.

more productive than Caldonazzo. The highest level of trophy was reached by Lake Caldonazzo in the seventies, when the Secchi disk values were 0.70-0.80 $\mathrm{m}$ and oxygen was absent below $4 \mathrm{~m}$ (Vittori 1985). In the seventies the effluents were collected and diverted outside the watershed and hypolimnetic oxygenation was applied. This led to a recovery of the lake to an extent that can be summarised by Secchi disk mean values of $1.55 \mathrm{~m}$ in 1976 and 5.20 in 1982. In the following years this last value was more or less constant (Vittori 1985). The most recent information (Gaggino \& Cappelletti 1984) confirms that both Lake Levico and Lake Caldonazzo are eutrophic, but the trophic level of the latter is higher than that of the former, with the nutrient concentrations in the water of Lake Caldonazzo higher than those in Lake Levico. For example, the mean nutrient concentrations in Lake Caldonazzo are the following: P-PT $=119 \mu \mathrm{g} \cdot 1^{-1} ; \mathrm{P}_{-} \mathrm{PO}_{4}=86 \mu \mathrm{g} \cdot \mathrm{l}^{-1}$; N$\mathrm{NO}_{3}=445 \mu \mathrm{g} \cdot \mathrm{l}^{-1} ; \mathrm{N}-\mathrm{NH}_{4}=148 \mu \mathrm{g} \cdot \mathrm{l}^{-1}$. The mean nutrient concentrations in Lake Levico are: P-PT $=67$ $\mu \mathrm{g} \cdot 1^{-1} ; \mathrm{P}-\mathrm{PO}_{4}=21 \mu \mathrm{g} \cdot \mathrm{l}^{-1} ; \mathrm{N}-\mathrm{NO}_{3}=147 \mu \mathrm{g} \cdot \mathrm{l}^{-1}$ and $\mathrm{N}-$ $\mathrm{NH}_{4}=88 \mu \mathrm{g} \cdot \mathrm{l}^{-1}$.

The 1984 census counted 15,500 inhabitants in the Lake Caldonazzo watershed, and 2,200 in the watershed of Lake Levico. The corresponding population densities are 366 inhabitant $\mathrm{km}^{-2}$ for Lake Caldonazzo and 85 $\mathrm{km}^{-2}$ for Lake Levico.

Tab. 1. The most important characteristics of Lake Levico and Lake Caldonazzo (data from Gaggino \& Cappelletti 1984).

\begin{tabular}{lcc}
\hline & LEVICO & CALDONAZZO \\
\hline altitude $(\mathrm{m})$ & 440 & 450 \\
lake surface $\left(\mathrm{km}^{2}\right)$ & 1.16 & 5.60 \\
max depth $(\mathrm{m})$ & 38 & 49 \\
mean depth $(\mathrm{m})$ & 11.10 & 26.50 \\
lake volume $\left(\mathrm{m}^{3} \cdot 10^{6}\right)$ & 12.9 & 149 \\
wastewater surface $\left(\mathrm{km}^{2}\right)$ & 27 & 47.9 \\
watershed $/$ lake surface & 23.30 & 8.55 \\
mean outlet $\left(\mathrm{m}^{3} \cdot \mathrm{s}^{-1}\right)$ & 0.43 & 1.29 \\
water renewal time $(\mathrm{y})$ & 1.0 & 3.6 \\
\hline
\end{tabular}

Traditional agriculture is carried on in the lower part of the Lake Caldonazzo watershed, and intensive orchards have spread over most of the flood-plain since the 1960s. Tourism also started at this time, and most of the shore is now occupied by campsites and hotels. 
In the past, the Lake Levico watershed was used for grazing and vineyards. In recent years these activities have gradually declined, and most of the watershed is now covered by mixed woodlands. Tourism is very limited.

These data explain the higher trophic level of Lake Caldonazzo than that of Lake Levico.

\section{MATERIAL AND METHODS}

Samples of Unio pictorum, L. were collected from Lake Levico and Lake Caldonazzo during July 2001. The mussels were collected by hand from the littoral zone at a maximum depth of about 1 meter. The film of sediments and algae coating the external surface of the shell was scrubbed off with a nylon nailbrush. The soft tissues of the individuals from each lake were removed from the shell and rejected; the shells were washed with filtered lake water and dried to room temperature.

The shells from each lake were pulverized and mineralized using $\mathrm{HNO}_{3}$ and $\mathrm{H}_{2} \mathrm{O}_{2}$ at $180{ }^{\circ} \mathrm{C}$ and a pressure of 1300 psi. The solution obtained was analyzed for $\mathrm{Ca}, \mathrm{Al}, \mathrm{Cu}, \mathrm{Zn}, \mathrm{Fe}$ and $\mathrm{Mn}$ by ICP-OES spectrometer (Jobin Yvon JY24 model). These analyses were performed by G.M. Beone and co-workers (Istituto di Chimica Agraria e Ambientale, Università Cattolica del Sacro Cuore, Piacenza, Italy). The same solution was analyzed for $\mathrm{Be}, \mathrm{V}, \mathrm{Cr}, \mathrm{Ni}, \mathrm{As}, \mathrm{Mo}, \mathrm{Cd}, \mathrm{Pb}$ and $\mathrm{Co}$ by ICP-MS by P.R. Trincherini and co-workers (Joint Research Centre of European Commission, IES - Ispra, Varese, Italy). The same metals were analyzed by the same methods in Unio pictorum shells collected in 1934 from Lake Levico and Lake Caldonazzo and preserved without chemical biocides at the Museo Tridentino di Scienze Naturali (Trento, Italy). The age of these mussels, like those collected in 2001, was estimated by counting the annual growth rings.

Samples of filtered water (Millipore $0.45 \mu \mathrm{m}$ pore size) collected from each lake during the 2001 sampling were analysed for $\mathrm{Fe}, \mathrm{Mn}, \mathrm{Zn}, \mathrm{Cu}, \mathrm{Al}$ and $\mathrm{Ca}$.

In a previous study (Ravera et al. 2003) to check the accuracy of the analytical procedure some reference material were analysed (BCR-CRM 278 mussel tissues; NIST-SRM 2711 soil and BCR-CRM 280 river sediments).

A more detailed description of sample preparation and analysis is reported in Ravera et al. (2003).

\section{RESULTS}

In 1934, as in 2001, the concentration of 15 metals in the shells from Lake Levico is always higher than that in the shells from Lake Caldonazzo (Tab. 2). The metal concentrations in the shells sampled from each lake in 1934 are very different from those collected in 2001; this is more evident for Lake Levico than for Lake Caldonazzo.

A comparison of the metal concentrations in the shells from the 1934 sampling with those from the 2001 campaign yields the following conclusions: a) in the shells from Lake Levico, the concentration of 11 metals (Zn, Cd, As, Al, Pb, Cu, V, Co, Mo, Fe Mn), out of 15 analyzed, increased from $14 \%(\mathrm{Mn})$ to $54 \%(\mathrm{Zn}), 3$ decreased $(\mathrm{Ni}, \mathrm{Cr}, \mathrm{Be})$ from $44 \%(\mathrm{Ni})$ to $89 \%(\mathrm{Be})$, and calcium concentration did not vary; b) in the shells from Lake Caldonazzo, the concentration of 6 metals (V, Fe, $\mathrm{As}, \mathrm{Co}, \mathrm{Zn}, \mathrm{Cd})$ out of 15 increased from $17 \%(\mathrm{Cd})$ to $540 \%(\mathrm{~V})$ and 6 decreased $(\mathrm{Cu}, \mathrm{Cr}, \mathrm{Pb}, \mathrm{Mn}, \mathrm{Ni}, \mathrm{Be})$ from $8 \%(\mathrm{Cu})$ to $86 \%(\mathrm{Be})$; calcium, aluminium and molybdenum concentrations did not vary (Fig. 2).

Tab. 2. Mean concentrations of metals in the shell of Unio pictorum, L. collected in 1934 and 2001 from Lake Levico and Lake Caldonazzo. Calcium concentration is expressed in $\mathrm{mg} \cdot \mathrm{g}^{-1}$ dry weight; those of the other elements are expressed in $\mu \mathrm{g} \cdot \mathrm{g}^{-1}$ dry weight.

\begin{tabular}{lccccc}
\hline & \multicolumn{2}{c}{ LEVICO } & & \multicolumn{2}{c}{ CALDONAZZO } \\
\cline { 2 - 3 } \cline { 5 - 6 } & 1934 & 2001 & & 1934 & 2001 \\
\hline $\mathrm{Ca}$ & 358 & 351 & & 356 & 336 \\
$\mathrm{Fe}$ & 660 & 1017 & & 188 & 686 \\
$\mathrm{Mn}$ & 549 & 626 & & 524 & 469 \\
$\mathrm{Zn}$ & 5.90 & 38 & & 5.90 & 14 \\
$\mathrm{Al}$ & 62 & 213 & & 52 & 53 \\
$\mathrm{Ni}$ & 10.46 & 5.83 & & 9.36 & 5.60 \\
$\mathrm{Cu}$ & 4.65 & 12 & & 4.10 & 3.75 \\
$\mathrm{As}$ & 8.02 & 30 & & 3.13 & 9.63 \\
$\mathrm{~Pb}$ & 1.43 & 4.49 & & 1.02 & 0.93 \\
$\mathrm{Cr}$ & 1.23 & 0.53 & & 0.56 & 0.51 \\
$\mathrm{~V}$ & 0.15 & 0.34 & & 0.05 & 0.32 \\
$\mathrm{Co}$ & 0.81 & 1.45 & & 0.48 & 1.29 \\
$\mathrm{Mo}$ & 0.09 & 0.16 & & 0.08 & 0.08 \\
$\mathrm{Cd}$ & 0.06 & 0.36 & & 0.06 & 0.07 \\
$\mathrm{Be}$ & 0.09 & 0.01 & & 0.07 & 0.01 \\
\hline
\end{tabular}

Figure 3 schematizes the percent difference between the lakes of each metal concentration in the shells for 1934 and 2001. This figure shows clearly that: a) the differences for the same year vary widely with the metal, and b) the difference of the concentration of the same metal calculated for 1934 is often very different from that calculated for 2001. For example, the percent difference of arsenic in the shells of both the lakes is of the same order of magnitude in 1934 and 2001, while the differences between the lakes for zinc and cadmium are equal to zero in 1934 and respectively $63 \%$ and $80 \%$ in 2001.

The concentrations of 6 metals $(\mathrm{Fe}, \mathrm{Mn}, \mathrm{Zn}, \mathrm{Cu}, \mathrm{Al}$, $\mathrm{Ca}$ ) in the filtered water sampled in 2001 from Lake Caldonazzo are higher than those from Lake Levico; the sole exception is calcium, which has a higher concentration in the water from Lake Levico (Tab. 3).

\section{DISCUSSION AND CONCLUSIONS}

The metal load to both lakes derives, at least in part, from springs and the water-table, which are rich in metals originating from the erosion and dissolution of the watershed rocks. The mining activity (e.g. of $\mathrm{Fe}, \mathrm{Cu}$, $\mathrm{Ag}, \mathrm{Pb}$ and $\mathrm{Zn}$ ) carried on in the Lake Levico and Lake 

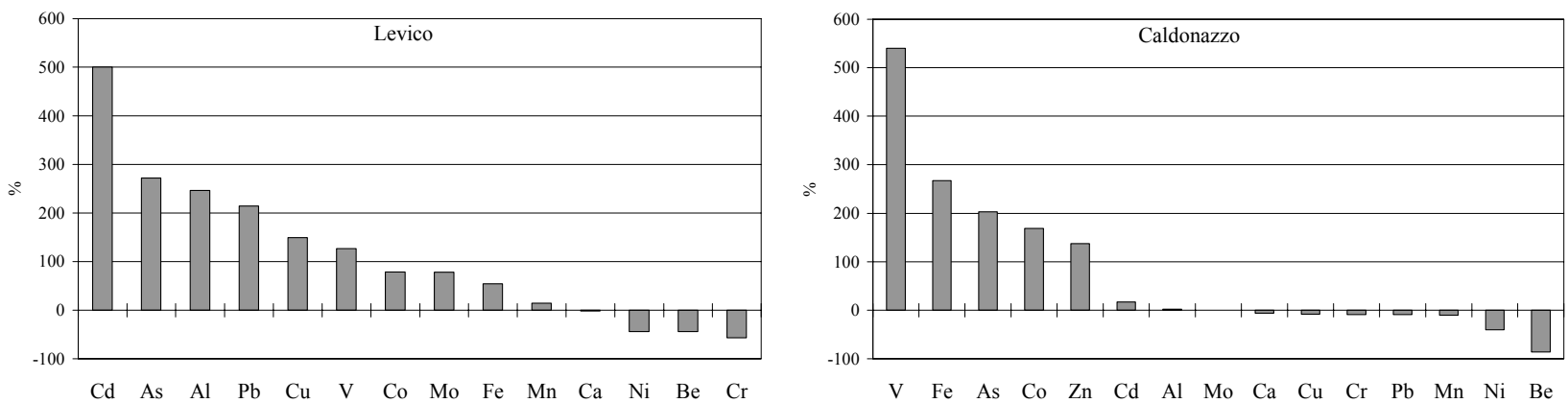

Fig. 2. Percent variations of the metal concentrations in the shells of Unio pictorum from 1934 to 2001 in Lake Levico and Lake Caldonazzo.

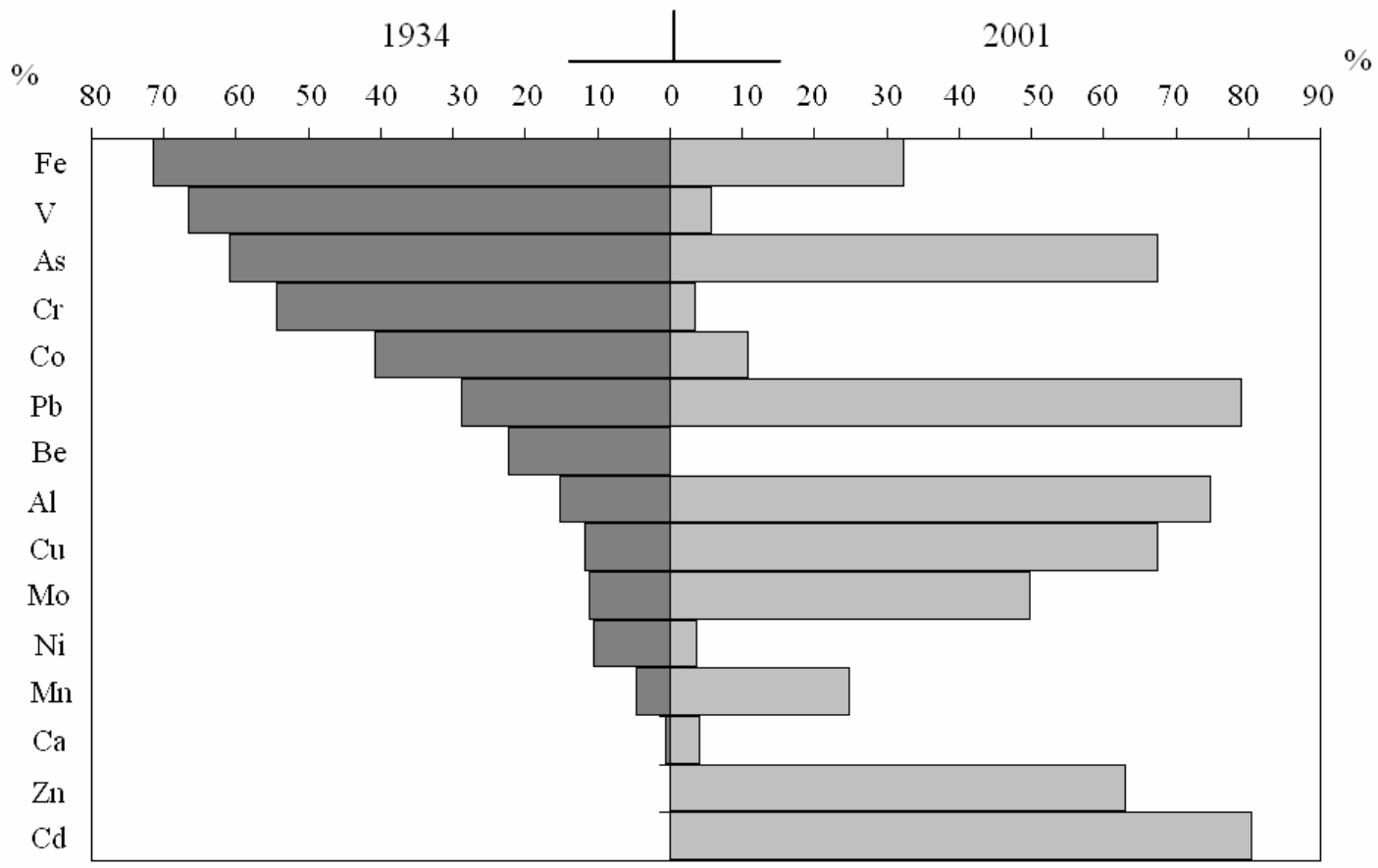

Fig. 3. Differences between the metal concentrations in the shells from Lake Levico and Lake Caldonazzo calculated from 1934 and 2001 samplings. $\% \mathrm{x}=100 \cdot(\mathrm{a}-\mathrm{b}) / \mathrm{a}$; where: $\% \mathrm{x}=$ per cent difference; $\mathrm{a}=$ metal concentration in the shells from Lake Levico; $\mathrm{b}=$ metal concentration in the shells from Lake Caldonazzo.

Caldonazzo area from the $16^{\text {th }}$ to $18^{\text {th }}$ centuries testifies to the wealth of heavy metals in these rocks.

Tab. 3. Mean concentration of metals in filtered water (0.45 $\mu \mathrm{m}$ pore size) from Lake Levico and Lake Caldonazzo. The calcium concentrations are expressed in $\mathrm{mg} \cdot \mathrm{l}^{-1}$, those of trace metals in $\mu \mathrm{g} \cdot \mathrm{l}^{-1}$.

\begin{tabular}{lcc}
\hline & LEVICO & CALDONAZZO \\
\hline $\mathrm{Fe}$ & 26.70 & 75.30 \\
$\mathrm{Mn}$ & 2.20 & 9.88 \\
$\mathrm{Zn}$ & 10.90 & 12.21 \\
$\mathrm{Cu}$ & 1.01 & 1.56 \\
$\mathrm{Al}$ & 24.10 & 184.00 \\
$\mathrm{Ca}$ & 21.15 & 19.64 \\
\hline
\end{tabular}

Because the age of the mussels from both samplings ranges from 5 to 7 years, the shells from each sampling reflect the environmental conditions during a well defined period of about 6 years: from 1928 to 1934 for the first sampling and from 1995 to 2001 for the second, with a time interval of about 61 years. The earliest information on the ecology of both lakes refers to the period 1947-1949 (Marchesoni 1952a; 1952b); Vittori (1985) monitored the lake from 1975 to 1984, and Gaggino \& Cappelletti (1984) published the available scientific results obtained in the 1980 s. There is thus no information on the trophic level of these lakes corresponding to either of our sampling periods.

If we are to acquire a better knowledge of the causes of the different metal concentrations in mussels from 
different environments, the concentration of metals in the water must be known, in addition to the concentrations of the same metals in the shells. Unfortunately, only the concentrations of six metals ( $\mathrm{Fe}, \mathrm{Mn}, \mathrm{Zn}, \mathrm{Cu}$, $\mathrm{Al}, \mathrm{Ca})$ were measured in filtered water from both lakes during the 2001 sampling. The concentrations of these relatively abundant metals were higher in the water of Lake Caldonazzo than those measured in Lake Levico (Tab. 3).

If we accept the hypothesis that the Lake Caldonazzo water is also richer in other metals than that of Lake Levico, we may conclude that the metal concentrations in the shells are higher in environments with lower concentrations of the same metals in the water. This apparent anomaly, observed in a previous research on metal concentrations in the same species (Unio pictorum) collected from 12 lakes, was presumed to be an effect of the trophic level of the lake (Ravera et al. 2003). In conclusion, the metal concentrations in a form available to the mussel in the water of the more productive Lake Caldonazzo are probably lower than those of the less productive Lake Levico. If this is true, it could explain the higher metal concentrations in the shells from Lake Levico than in those from Lake Caldonazzo, although the total metal concentrations in the water of Lake Caldonazzo are higher than those of Lake Levico.

The most important conclusions of our study are the following.

- The metal concentrations in the shell from Lake Levico are higher than those from Lake Caldonazzo, in 1934 as well as in 2001.

- From 1934 to 2001, the concentrations of 11 metals in the shells from Lake Levico increased and only 3 decreased. During the same interval of time the concentrations of 6 metals in the shells from Lake Caldonazzo increased and 6 decreased.

- In the shells from both lakes the percentages of metal increase are very high compared with those of metal decrease (Fig. 2).

The great differences between the concentrations of the same metals in mussels collected from two lakes in the same period of time (1934 and 2001), and the differences in each lake from 1934 to 2001, reflect undoubted differences between Lake Levico and Lake Caldonazzo and the variations in their ecological conditions over time. On the other hand, is important to identify the factors responsible for these differences. Variations in the total metal concentrations in the water seem to be the most important factor, and in fact this has been adopted as a basic concept in the commonly used monitoring by accumulator organisms.

Neither the present research nor a preceding study (Ravera et al. 2003) revealed any clear relationship between metal concentrations in the shell and soft tissues of mussels and those in filtered lake water. The probable causes influencing this relationship have been discussed in other papers (e.g. Ravera et al. 2003; Ravera 2004).

In our opinion, a better relationship should result if the metal concentration in the mussel is related to the concentration of the available forms of the metal in the water, and not to the total metal concentration (e.g. Zamuda \& Sunda 1982; Ravera 2004). Unfortunately this information is lacking.

However, this research demonstrates the usefulness of analysing metal concentrations in mussel shells to evaluate the variations over time of the environmental conditions of both of these lakes.

\section{ACKNOWLEDGMENTS}

We would like to thank Dr. Giovanna Lipparini (Museo Trentino di Scienze Naturali) for providing the shells collected in 1934 and the important publications on mussels from Lake Levico and Lake Caldonazzo, and Prof. Sandra Spence for the careful language revision of the manuscript.

\section{REFERENCES}

Carell, B., E. Dunca, U. Gärdenfors, E. Kulakowski, U. Lindh, H. Mutvei, J. Nyström, A. Seire, T. Slepukhina, H. Timm, T. Westermark \& V. Ziuganov. 1995. Biomonitoring of pollutants in a historic perspective. Emphasis on mussel and snail shell methodology. Ann. Chim., 85: 353-370.

Frantsevitch, L., A. Korniushin, I. Pankov, A. Ermakov \& T. Zachantjuk. 1996. Application of molluses for radioecological monitoring of the Chernobyl outburst. Environ. Pollut., 94: 91-100.

Gaggino, G.F. \& E. Cappelletti. 1984. Catasto dei laghi italiani. Vol. I - Italia Settentrionale. Quaderni IRSACNR, 72.

Imlay, M.J. 1982. Use of shells of freshwater mussels in monitoring heavy metals and environmental stresses: a review. Malacol. Rev., 15: 1-14.

Marchesoni, V. 1952a. Ricerche idrobiologiche ai laghi di Caldonazzo e Levico: Dati ambientali e loro correlazioni con la produttività fitoplanctonica. In: Ricerche limnologiche: I laghi di Caldonazzo e di Levico. Vol. I C.N.R., Bologna: 1-95.

Marchesoni, V. 1952b. Ricerche idrobiologiche ai laghi di Caldonazzo e Levico: Insediamenti algologici pelagici, litorali e bentonici. In: Ricerche limnologiche: I laghi di Caldonazzo e di Levico. Vol. I - C.N.R., Bologna: 97-197.

Mutvei, H. \& T. Westermark. 2001. How environmental information can be obtained from Naiad shells. In: G. Bauer and K. Wachtler (Eds), Ecology and evolution of the freshwater mussels Unionida. Ecological Studies, 145. Springer Verlag, Berlin: 367-379.

Nelson, D.J. 1964. Deposition of strontium in relation to morphology of clam (Unionidae) shells. Verh. int. Ver. Limnol., 15: 893-902.

Nyström, J., E. Dunca, H. Mutvei \& V. Lindh. 1996. Environmental history as reflected by freshwater pearl mussels in the River Vramsån, southern Sweden. Ambio, 15: $350-355$.

Ravera, O. 2004. Importance and difficulties of research on the metal speciation in the aquatic ecosystem: an ecologist's viewpoint. Annali di Chimica, 94: 495-504.

Ravera, O., G.M. Beone, R. Cenci \& P. Lodigiani. 2003. Metal concentrations in Unio pictorum mancus (Mollusca, Lamellibranchia) from of 12 Northern Italian lakes in relation to their trophic level. J. Limnol., 62(2): 121-138. 
Trener, G.B. 1952. L'origine geologica e l'idrografia dei laghi di Caldonazzo e di Levico. In: Ricerche limnologiche: I laghi di Caldonazzo e di Levico. Vol. I - C.N.R., Bologna: 31-41.

Vittori, A. 1985. Il Lago Caldonazzo. Esperienze di limnologia applicata dal 1975 al 1984. Prov. Auton. di Trento. Stazione Sperim. Agric. Foreste. Dip. Ecologico Prov.: $256 \mathrm{pp}$.

Westermark, T., B. Carell, S. Forberg, H. Mutvei \& E. Kulakowski. 1996. Freshwater unionid (Mollusca: Bivalvia) shells as environmental archives: methodology and observations. Bull. Inst. Océanogr. Monaco Spéc., 14: $73-81$.

Received: May 2005

Accepted: July 2005
Westermark, T., H. Mutvei, B. Carell, E. Dunca, A. Bignert, E. Kulakowski, J. Nyström, M. Olsson, A. Seire, T. Slepukhina, I. Ahlgren \& O. Wahlberg. 1997. How can mussel shells contribute to environmental history information? Development of paleoceanography as a new field of science. Commemorating 50thAnniv. Albatross Exp. 1947-48, R Swedish Acad. Sci., Stockholm, Abstr.

Zamuda, C.D. \& W.G. Sunda. 1982. Bioavailability of dissolved copper to the American oyster Crassostrea virginica. 1. Importance of chemical speciation. Mar. Biol., 66: 77-82. 